\title{
Nutrient composition, in vitro gas production and digestibility of fenugreek (Trigonella foenum-graecum) and alfalfa forages
}

\author{
Z Mir 1, SN Acharya 1, PS Mir 1, WG Taylor 1, MS Zaman 1, \\ GJ Mears 1, LA Goonewardene 2 \\ ${ }^{1}$ Agriculture and Agri-Food Canada, PO Box 3000, Main, Lethbridge, Alberta T1J 4B1; 2 Alberta Agriculture, \\ 7000, 113 St-Edmonton, Alberta T6H 5T6, Canada
}

The potential of using fenugreek as an alternate annual legume forage (Mir et al, 1993, Can J Anim Sci, 73, 993-996) was evaluated by conducting chemical analysis, in vitro dry matter disappearance (IVDMD) after incubation with rumen fluid for $48 \mathrm{~h}$ and gas production (Menke et al, 1979, J Agric Sci, 93,217-222). Fenugreek was grown in a greenhouse and samples were collected at 9,15 and 19 weeks of growth. In experiment 1 , fenugreek forage after nine weeks of growth contained more ash than alfalfa cut at $10 \%$ bloom, yet the IVDMD of fenugreek was greater than that of alfalfa. However, total gas produced $(a+b)$ was greater while lag time prior to initiation of gas production was lower for alfalfa relative to fenugreek. In experiment 2, fenugreek harvested at 15 and 19 weeks of age contained less protein than alfalfa. NDF content of fenugreek was highest after 19 weeks of growth. The IVDMD of fenugreek $(52.8$ and $53.9 \%)$ was greater $(P<0.05)$ than that of alfalfa $(47.7 \%)$. Total in vitro gas production was similar for forages, yet the rate of gas production was lower $(P<0.05)$ for fenugreek $(19 \mathrm{wk})$ than for alfalfa. The results suggest that the nutritive value of fenugreek forage is such that it may be used as an alternative to alfalfa cut at $10 \%$ bloom. Additional ruminant feeding trials are required to confirm these findings.

\begin{tabular}{|c|c|c|c|}
\hline & $\begin{array}{c}\text { Fenugreek } \\
9 \text { week of } \\
\text { growth }\end{array}$ & $\begin{array}{l}\text { Alfalfa } \\
\text { Early } \\
\text { bloom }\end{array}$ & SEM \\
\hline CP $(\%)$ & 17.3 & 14.4 & 0.90 \\
\hline ADF $(\%)$ & 29.4 & 28.8 & 0.25 \\
\hline NDF $(\%)$ & 32.6 & 40.4 & 1.20 \\
\hline _ignin $(\%)$ & 6.4 & 8.7 & 0.27 \\
\hline Ash (\%) & $15.4^{a}$ & $8.6^{\circ}$ & 0.24 \\
\hline $\operatorname{VDMD}(\%)$ & $59.5^{\mathrm{a}}$ & $47.7^{\mathrm{b}}$ & 1.50 \\
\hline$+b^{1}$ & $22.3^{b}$ & $23.4^{\mathrm{a}}$ & 0.30 \\
\hline 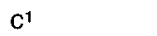 & 0.110 & 0.109 & .001 \\
\hline lag 1 & $0944^{a}$ & $0.615^{b}$ & 0095 \\
\hline
\end{tabular}

$\begin{array}{cccc}11.6^{\mathrm{b}} & 11.2^{\mathrm{b}} & 14.8^{\mathrm{a}} & 0.14 \\ 34.8 & 36.7 & 35.9 & 1.16 \\ 42.0^{\mathrm{b}} & 47.3^{\mathrm{a}} & 43.9^{\mathrm{b}} & 0.53 \\ 11.0 & 10.4 & 8.0 & 0.82 \\ 10.3 & 8.7 & 8.7 & 0.26 \\ 52.8^{\mathrm{a}} & 53.9^{\mathrm{a}} & 47.7^{\mathrm{b}} & 1.24 \\ 24.5 & 26.2 & 25.2 & 0.51 \\ 0.108^{\mathrm{ab}} & 0.101^{\mathrm{b}} & 0.123^{\mathrm{a}} & 0.005 \\ 0.324 & 0.447 & 0.397 & 1.11\end{array}$

a, $b$ Means in the same row with different superscripts are significantly different $(P<0.05)$

$1 \mathrm{a}+\mathrm{b}$ is potential gas production $(\mathrm{ml} / 100 \mathrm{mg} \mathrm{DM}), \mathrm{c}$ is rate constant of gas production $\left(\mathrm{h}^{-1}\right)$, lag is lag time (h) prior to initiation of gas production in the model $\mathrm{P}=\mathrm{a}+\mathrm{b}\left(1-\mathrm{e}^{-\mathrm{c}(\mathrm{t}-\mathrm{Lt})}\right)$ (McDonald, 1981, J Agric Sci, 96, 251-252). 